\title{
Theoretical Study of the A Truth-Seeking Learning Model: The Learning Model to Improve Students' Critical Thinking Disposition
}

\author{
$1^{\text {st }}$ Achmad Zanuar Ansori \\ Religious Education and Training \\ Center of Surabaya \\ Surabaya, Indonesia \\ zanuar_a@yahoo.com
}

\author{
$2^{\text {nd }}$ Muslimin Ibrahim \\ Biology Department \\ State University of Surabaya \\ Surabaya, Indonesia
}

\author{
$3^{\text {rd }}$ Wahono Widodo \\ Biology Department \\ State University of Surabaya \\ Surabaya, Indonesia
}

\begin{abstract}
Critical thinking studies were mostly aimed at improving critical thinking skills and placed a critical thinking disposition as a nurturing effect. Thus, critical thinking disposition is rare to practice including in learning Biology. Meanwhile, critical thinking disposition is required so that students are willing to consistent think critically. The studies also showed that the critical thinking disposition truth-seeking subscale scores the lowest among the six other subscales. This study tries to formulate a model of learning that fosters critical thinking disposition truth-seeking subscale. The method applied is literature study and study of previous research. Truth-seeking Learning Model is a model designed to be able to answer the above problems. The model is based on two existing learning models and various psychological theories. The psychological theories used are constructivism, social learning theory, Gestalt psychology, and motivational theory. The model consists of six phases, i.e., exposing issues and encouraging curiosity, guiding problem identification, guiding the collecting information process, reformulating issue and presenting results, evaluation and reflection, and integration.
\end{abstract}

Keywords: truth-seeking disposition, truth-seeking learning model

\section{INTRODUCTION}

Three groups of skills are demanded in the $21^{\text {st }}$ century. Learning skills and innovation as one group includes critical thinking skills and problem-solving [1]. Critical thinking skills are more needed in employment today than ever before [2]. The ability to think critically and problem-solving is the character required to be able to compete in this era [3].

The terminology of critical thinking is inseparable in the context of learning science, including Biology at the high school level. Learning biology is demanded to equip learners with critical thinking based on the potential of biological processes and products, to understand the natural phenomena around them, to make decisions among various choices, and to solve the problems using scientific consideration [4].

The affective dimension of critical thinking is often called critical thinking disposition. Critical thinking disposition is $a$ consistent internal motivation to engage problems and to make decisions by using CT [5]. In other words, the disposition of critical thinking is a tendency to think critically about facing problems and making decisions consistently. Critical thinking disposition itself consists of truth-seeking, open-mindedness, analyticity, systematicity, self-confidence, inquisitiveness, and intellectual maturity [6]. Therefore, critical thinking disposition is a group of habits of mind.

Some researches on the critical thinking disposition have been conducted. Such research has found similar results. Research reveals that truth-seeking and open-mindedness had the lowest average among the seven aspects of critical thinking disposition, 32.20 and 35.28 respectively with a maximum score of 60 [7]. The use of Problem-Based Learning (PBL) model can improve students' critical thinking dispositions on the seven aspects of critical thinking disposition, but truth-seeking and systematicity obtaining the lowest score of 41.4 and 41.5 from the maximum score of 70 [8]. Another research found that the truth-seeking has the lowest score of 35.39 from a maximum score of 70 [9]. Another research found the same thing [10-12]. Based on some researches above can be concluded the truth-seeking tend to always be the lowest average compared with six other critical thinking disposition aspects.

Critical thinking skills are influenced by critical thinking dispositions. Critical thinking skills alone are not sufficient enough for a person to always think critically. Such a person must possess the disposition or motivation of critical thinking to carry out critical thinking [13]. Furthermore, they assert that one can understand and master critical thinking skills. However, the person cannot apply it because of the unsupported learning situation. Critical thinking dispositions are needed to support someone always to think critically [14]. Critical thinking disposition is necessary for a critical thinker to have ethics, not to exploit others and to have good personal and social feelings [6].

So far, learning practice related to critical thinking is much more conducted in the effort of improving critical thinking skills. Learning to build critical thinking disposition becomes essential. In consequence of this, it is necessary to develop a learning model that can foster the disposition of students' critical thinking especially on the aspect of truthseeking, including on Biology learning. A learning model that uses questions as a basis for its development as found in the PBL model [15-17].

\section{METHODS}

This study has aim to develop a hypothetical learning model. The learning model intended to improve students' critical thinking disposition in truth-seeking subscale. The study used a literature review method. The stages implemented are problem formulation, data collection, data evaluation, analysis and interpretation, and public 
presentation [18]. The problem formulation started by finding that there was a need to develop a learning model to improve students' critical thinking disposition in truth-seeking subscale. In the data collection stage, we collected relevant articles and books to truth-seeking disposition, how to grow disposition, learning theories, motivational theory, and learning models in both theoretical and empirical study. Then we selected which literature is useful, informative and related to the main focus of this study. In the analysis and interpretation, a hypothetical learning model was built by synthesizing two existing learning models.

\section{RESULT AND DISCUSSION}

\section{Truth-seeking Disposition}

Students with a truth-seeking disposition include having a courageous desire to seek the best knowledge according to a given situation, asking awkward questions, willing to follow reason and evidence even though the results are contrary to prejudice or self-interest [15]. A truth-seeker prefers to truth rather than lying and dedicating to seeking the truth in all things [19].

Truth-seeking spreads over some of the existing intellectual traits. A person with intellectual courage should not be passive and uncritical of ideas even though the ideas are sometimes dangerous and absurd, but such a condition accepted as truth. Intellectual braveness says critical thinkers should seek information about the truth. Intellectual autonomy states the need to commit to analyze and to evaluate beliefs by using reason and evidence as a basis [20]. The point is that truth-seeking can be realized in the form of a passion and dedication always to seek the truth. Someone can ask questions until the truth is gained. Critical thinkers view knowledge and truth as goals that must be strived to achieve [21]. Developing the knowledge and understanding thoroughly about the problems is a challenging process. The ability to explore and to analyze is needed along with the growth and development of such knowledge and understanding.

The truth-seeking is a process that requires many actions. A critical thinker must analyze and evaluate the amount of information available [22]. The critical thinker should be able to determine which information is correct and to require further testing and be able to realize that they do not have enough information to make a reasonable conclusion. So, they should seek additional information. Many people believe in truth based on what they read or hear from a single source [23]. They do not check the source's truth by comparing other sources. Comparing information from multiple sources is not just a guide to truth. Comparison of information from various sources also provides information about different points of view about the problem. Thus, there is a space for errors and further research.

Most societies practice a habit of believing that knowledge and truth are absolute and irreversible. One of the primary goals of social institutions, including the family and the school, is to transfer the knowledge that has been growing for so long, even centuries [21]. This situation leads students as a passive individual in learning. On the other hand, there is a view that students should be active and responsible in the learning process.

A person can be more skeptical or credulous [22]. Experience or personality trait cause this. Critical thinking is concerned with the use of a set of specific methods aimed at exploring evidence in a particular way. A skeptical person will use a structured approach to generate possible solutions to problems.

Students cannot separate themselves from the abundance of information in their everyday life with varying degrees of truth. Such information may be an issue that is sometimes controversial from a scientific or biological point of view. Thus, choosing which information needs attention and knowing how to consider the evidence that can be expected as facts is a necessary skill in the information age. As an information consumer, students should be able to differentiate which the fact-supported claims and which rely solely on 'truthiness,' or to use feelings rather than empirical evidence [24]. Truthiness is defined as the quality to prefer the concepts or facts that people want to be true, not concepts or facts that are known or known to be true [25]. This becomes a challenge in the educational world.

Issues have a prominent place in learning science. There are three reasons to accommodate even controversial issues in learning science [26]. First, the use of issues makes content more engaging, meaningful, challenging, and relevant so that student engagement and motivation increase. Second, the use of the issue can illustrate the reality of the scientific nature. Third, students gain attitudes, skills, and understanding of essential processes by examining controversial issues related to science. Moreover, the use of issues brings the students to learn to weigh evidence, to seek information, to detect biases, questioning the validity of sources and to show their own point of view. Thus, skills in communication, listening, and collaborative work can be improved. The controversial issue has at least two conditions. First, there is a scientific debate or disagreement about causes, theories, and evidence. Second, the debate or disagreement with regards to the application of science and its effects on the environment, human or animal.

A particular characteristic of truth-seeking disposition is being eager to find the best knowledge based on the existing context, to be dare to ask questions, to be honest, and objective in conducting an investigation. Although, if the findings do not support a person's prior interest or opinion, to tend to adjust its beliefs following relevant and robust facts and reasons, to receive essential considerations regarding facts, reasons and other perspectives, and evaluate new information and evidence [27].

\section{Growing Disposition}

Attitudes can change and develop so it may be increased. The development of attitudes undergoes a particular stage, not at once [28]. A character is a reliable disposition in responding to a situation and has three parts of moral knowing, moral feeling, and moral behavior [29]. The disposition that has reached moral behavior stage means it becomes a character. 
Truth-seeking disposition can be grown or formed through stages of moral knowing, moral feeling, and moral behavior [29]. The formation of truth-seeking disposition begins with the provision of knowledge and understanding of the importance of the truth-seeking disposition for each student (moral knowing). The purpose of this stage is that students know the truth-seeking disposition. However, students are not expected to know or to understand what and how to find the truth, only. Students should be aware of the importance of having the truth-seeking disposition (moral feeling). The next stage is the emergence of consciousness to use the disposition of truth-seeking (moral behavior). If the student always uses the truth-seeking disposition against the issue, then the disposition has become part of the student's or character. The three components are interrelated, mutually, penetrating, and influencing each other [29]. For good attitude learning outcomes, the learning process must be deliberately planned, implemented and evaluated the level of achievement [30]. Learning attitudes can be expected to achieve better results by considering the stages of attitude formation as described above.

So far, research that tries to develop a model of learning to cultivate truth-seeking disposition has not been done yet. Learning model that is often used and linked to critical thinking is the Problem-Based Learning model (PBM). Another learning model associated with the development of the affective domain is a non-directive model developed by Rogers [31].

\section{Developing hypothetical model}

This hypothetical model is designed primarily to make students more actively seek out the necessary information related to the issues or problems presented. The learning phases of this model are designed to foster the disposition of students' truth-seeking deliberately. The hypothetical model places the truth-seeking disposition as the primary goal of model development.

The development of this hypothetical model is designed based on two previous learning models that already exist, Problem Based Learning (PBL) and nondirective. Key ideas in PBL adapted and adopted in the hypothetical models include the use of issues or problems as learning entrances and group discussions to open insights. Non-directive characteristics related to self-growth and self-development is expected to foster the truth-seeking disposition. Then, a new model that is more specialized in developing the disposition of truth-seeking is synthesized, called Truth-seeking Learning Model (TLM). The synthesizing process can be seen in Fig. 1.

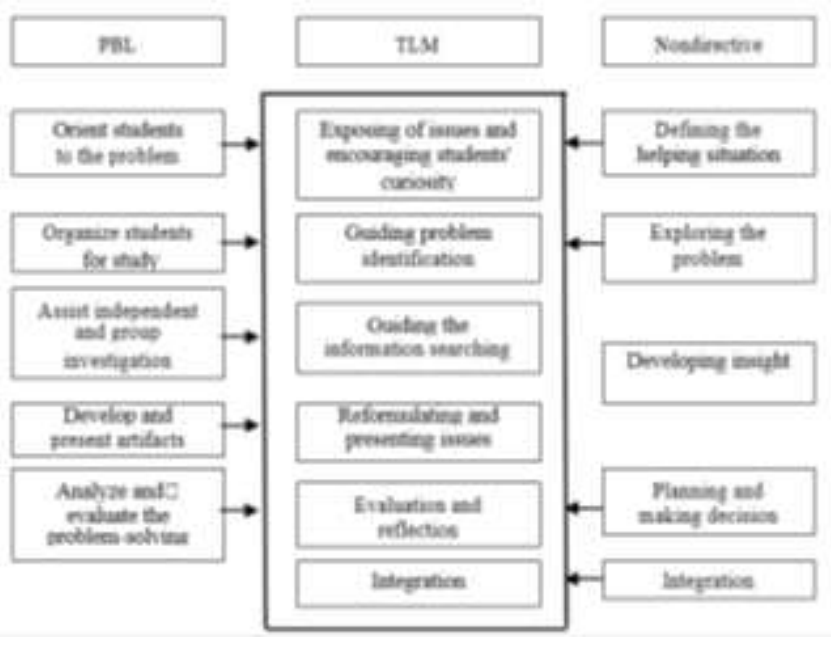

Fig. 1. Synthesis of the TLM

Some characteristics of the TLM include:

1. The use was of issues or problem both controversial and related to public belief. These issues or problem are related to biology that is close to the students' daily life. 2. The use of feeling expressed in the early stages as part of nondirective aims to determine the extent of student responses to issues or problems given.

3. Learning stages are arranged in such a way in order the formation of truth-seeking dispositions is done through the process of moral knowing, moral feeling, and moral acting.

4. Learning ends with the integration stage. The teacher guides the students to integrate attitudes by giving tasks to ascertain the students' initiate doing follow-up activities.

The TLM starts learning activities with individual activities followed by group activities then returns to individual activities. This process is expected to foster a truthseeking disposition in more number of students. The integration phase which is the final phase of the TLM is designed to help students build awareness about the importance of having a truth-seeking disposition and to actualize action. The syntax of the TLM consists of six phases. Below is a description of each learning phase of the TLM model.

Phase 1: Exposing issues and encouraging of students' curiosity

This phase is designed to attract students' attention and to grow curiosity and interest which is essential to understand information [32,33]. The use of issues makes the content more interesting, meaningful, challenging, and relevant so that students' involvement and motivation increase [26]. Then, meaningful learning happens where the students connect new information with their existing knowledge [16]. The use of new issues or problems and connected to students' daily life is believed to be able to generate and to maintain the level of student attention [34]. Psychology Gestalt states learning as a cognitive activity that involves the rearrangement of experiences about objects, people or events as an organized unity. 
Another activity is to express curiosity. Disclosure of the curiosity toward the existing situation permissively allows students to answer freely and show their interest [31]. The motivational theory emphasizes the importance of creating a fun and safe learning environment in which students can be responsible for their learning or positive feeling tone [17]. The students also asked to respond to the issues. Some questions are the importance of the issues and what happens if they ignore the issue. It will be beneficial for students to develop questions about learning materials for themselves both before and after they learn the materials [35]. Making their question will facilitate self-understanding. This step is done to introduce the truth-seeking disposition (moral knowing) [29].

\section{Phase 2: Guiding problem identification}

This phase begins with the identification of concepts and statements contained in issues or problems. The statements intended are not understandable, vague or unclear, and scientifically incorrect. Students identify and define all concepts individually. Students who are cognitively involved in the process of defining problems will be actively involved in learning [36]. Students are very likely to provide different definitions for the same concept. Other students can help to reduce their egocentricity [34]. Therefore students must have a strategy on how to control all aspects of learning [16].

Phase 3: Guiding the information searching process

At this stage, students are encouraged to seek information individually. It is expected that the students aware of the importance of having a truth-seeking character (moral feeling) and act to seek information (moral acting) [29]. The process of gathering information can be accomplished by hand on activity and literature review [37]. The traditional education system is suspected to be involved in inhibiting the development and encouraging critical thinking among students especially the search for truth because students tend to receive ready-made information from teachers [38].

Phase 4: Reformulating and presenting the issues

The student brings the information to be discussed in the group which is heterogeneously in academic ability [39]. The students rearrange the issue, and they can add supporting data. Each student is expected to bring and deliver the information obtained in the third phase. Students need to negotiate to determine more appropriate information. The truth of information given by each is tested in groups.

Through this activity, the importance of having the character of the truth-seeking (moral feeling) is expected to grow.

In the group, social interaction can serve as learning [34]. Individuals can deliver information obtained in phase three. Students work together to complete the learning task. The students are believed to be able to solve problems under adult guidance or through collaboration with more capable peers [16]. Therefore in this phase students are expected through the process of cognitive apprenticeship. Teachers can provide help if needed.
The use of issues in fostering the truth-seeking disposition demands students learn to weigh evidence, seek information, detect biases, question the validity of sources and then present their viewpoints [26]. Other students in the group tested the initial thinking presented in the first phase and the acquisition of information in the third phase. This interaction encourages students to convey their thoughts and to rearrange them by comparing to the other students' thinking [40]. Therefore, each student must expand knowledge, be able to find the leak or weaknesses of his knowledge if they want to build mutual understanding [16]. In the group, the students are stimulated to express their opinions, to hear the opinions of other students, and reason correctly through the negotiation process [41]. Students share their individual views with other students to build a shared understanding that cannot be undertaken alone or individually [16].

The primary activity in this phase is the presentation in front of the class. Other groups may respond or ask to reinforce the information provided. When a student shares knowledge, his knowledge will become stronger as they are encouraged to clarify and organize ideas conveyed so that they can be understood and be accepted by others [16]. Highlevel cognitive processes are expected to occur along with the network of experience in the brain [34]. This phase also serves to train students doing oral communication and convince other groups of the accuracy of the information presented.

\section{Phase 5: Evaluation and reflection}

This phase is intended to help students analyze and evaluate their work including the process of getting information. The teacher provides feedback to students regarding their work. This feedback is crucial because it can serve as an incentive or reward which lead to learning motivation [33]. Without feedback, the knowledge gained will be slight [17]. The feedback should be specific and as soon as possible to obtain the correct one [17]. The presence of the teacher with all the information provided is significant. Self-evaluation is expected to happen where students are able to make decisions on learning outcomes [16]. During this phase, the teacher asks the students to reconstruct the thoughts and activities that have been done during the learning process. This step ends with a reflection on the way the learning process guided by the teacher.

\section{Phase 6: Integration}

The integration phase is carried out in order to create truth-seeking disposition as a new orientation becoming part of the student's self. Students try to develop more decisive actions to solve problems and provide correct answers. The integration phase occurs when students feel that their regular action has consequences for themselves. The provision of stimuli, testing, and assessment of new perceptions have an essential position for the integration process [42]. At the end of this phase, students are asked to construct their questions related to learning materials following the results of evaluations by teachers and students. 


\section{CONCLUSION}

There is a need to develop a model promoting truthseeking disposition based on literature review and study of previous research. The Truth-seeking Learning Model is a model designed to improve the truth-seeking disposition. The model consists of six phases in which each phase is designed to grow such a disposition in a particular stage. The development of the TLM is supported by various psychological theories such as constructivism, social learning theory, Gestalt psychology, and motivational theory. Further examination is required to see the robustness of the TLM through implementation in classrooms.

\section{REFERENCES}

[1] B. Trilling, and C. Fadel, 21st Century Skills: learning for life in our times, Jossey-Bass, San Francisco, 2009, pp. 48-49.

[2] S. Sendag, and F. Odabas1, "Effects of an Online Problem Based Learning Course On Content Knowledge Acquisition And Critical Thinking Skills," Computers \& Education vol. 53, pp. 132-141, 2009.

[3] Partnership for 21st Century Skills, P21's Framework for 21st Century Learning, http://www.p21.org/abouts/p21-framework, Accessed November 72014

[4] Ministry of National Education, The Core Competence, and Basic Competence on Curriculum 2013 at Basic and Middle Education, Jakarta, 2016.

[5] P. A. Facione, N.C. Facione, and C.A. F. Giancarlo, "The Disposition Toward Critical Thinking: Its Character, Measurement, and Relationship to Critical Thinking Skill”, Informal Logic, vol. 20, pp. 61-84 2000.

[6] P. A. Facione, Critical Thinking: What It Is and Why It Counts, Measured Reasons LLC, Hermosa Beach, California, 2015, pp. 12.

[7] D. A. El-Demerdash, Z. I. El Hawashy, S.A.A. Donia, and E.E. Taha, "Preferred Educational Strategies and Critical Thinking Dispositions among Nursing Students," Journal of American Science, vol. 7, pp. 406-416, 2011.

[8] X, Y. Du, J. Emmersen, E. Toft, and B. Sun, "PBL and critical thinking disposition in Chinese medical students - A randomized cross-sectional study," Journal of problem-Based Learning in Higher Education, vol. 1, pp. 72-83, 2013.

[9] Hsiang-Chu. Pai and Eng. Cheng-Joo, "The relationships among critical thinking disposition, caring behavior, and learning styles in student nurses," Open Journal of Nursing, vol. 3, pp. 249-256, 2013.

[10] F. Ojewole and C. Thompson, "Assessment of Critical Thinking Dispositions of Nursing Students in Southwestern Nigeria," International Journal of Research in Applied, Natural and Social Sciences, vol. 2, pp. 7-16, 2014.

[11] H. Z. Hossein, K. Nasrin, H Khalkhali, and Y. Mohammad pour," Effect of evidence-based nursing on critical thinking disposition among nursing students," Life Science Journal, vol. 11, pp. 487-491, 2014.

[12] A. El-Shaer and H. Gaber, "Impact of Problem-Based Learning on Students`Critical Thinking Dispositions, Knowledge Acquisition and Retention". Journal of Education and Practice, vol. 5, pp. 74-85, 2014.

[13] A. M. Nieto and C. Saiz, "Skills and dispositions of critical thinking: are they sufficient?” Anales de Psicología, vol. 27, pp. 202-209, 2011.

[14] Z. Arsal, "The Effects of Microteaching on the Critical Thinking Dispositions of Pre-service Teachers," Australian Journal of Teacher Education, vol. 40, pp. 140-153, 2015.

[15] H.J Walton, and M.B. Matthews, in M. Savin-Baden, and C.H. Major, "Foundations of Problem-based Learning," Open University Press, Berkshire, 2004, pp. 6.

[16] R. Moreno, Educational Psychology. John Wiley \& Sons, Inc., River Street, Hoboken, NJ, 2010.

[17] R. I. Arends, Learning to Teach (9th Edition), McGraw-Hill, New York, 2012.

[18] J. J. Randolph, "A Guide to Writing the Dissertation Literature Review," Practical Assessment, Research \& Evaluation, vol 14, pp.112, 2009.

[19] C. Chadwick, "Teaching Kids to Think Critically," The Rowman \& Littlefield Publishing Group, Inc., Lanham, Maryland, 2014, pp.123.
[20] R. Paul, and L. Elder, The Miniature Guide Critical Thinking Concepts and Tools, 2008.

[21] J. Chaffee, Thinking Critically (10th Edition). Wadsworth Cengage Learning, Boston, MA, 2012.

[22] J. Chaffee, The Philosopher's Way: Thinking Critically about Profound Ideas (4th Edition). Pearson Education, Inc., Upper Saddle River, NJ, 2013.

[23] S. Cottrell, "Critical Thinking Skills: Developing Effective Analysis and Argument," Palcrave Macmillan, New York, N.Y, 2005, pp. 135.

[24] S. Colbert, The Colbert Report, Comedy Central. "Deal or No Deal Countries" (2005), (http://www.cc.com/shows/ the-colbert-report, Accessed June 122013.

[25] Merriam-Webster's, "Word of the Year," (2006), http://nws.merriamwebster.com/opendictionary/newword_search.php?word=truthiness, Accessed May 172016.

[26] J. Wellington, Teaching, and Learning Secondary Science: Contemporary Issues and Practical Approaches, Taylor \& Francis, New York, 2002.

[27] P. A. Facione, C.A. Giancarlo, N.C. Facione, and J. Gaines, "The Disposition toward Critical Thinking," Journal of General Education, vol. 44, pp. 1-25, 1995.

[28] W. Gulo, Strategi Belajar Mengajar, Grasindo, Jakarta, 2002.

[29] T. Lickona, Educating for Character: How Our School Can Teach Respect and Responsibility, Bumi Aksara, Jakarta, 2013.

[30] M. Ibrahim and Wahyusukartiningsih, Model Pembelajaran Inovatif melalui Pemaknaan belajar perilaku positif dari alam, Unesa University Press, Surabaya, 2014.

[31] C.R. Rogers, On Becoming a Person: A Therapist's View of Psychotherapy, Houghton Mifelin Company, Boston, 1961.

[32] J. M. Keller, Motivational Design of Instruction. In C.M. Reigeluth (Ed). Instructional Design Theories and Models: An Overview of Their Current Status. Erlbaum, Hillsdale, NJ, 1983.

[33] R. E. Slavin, Educational Psychology: theory and practice 8th Edition, Pearson Education, Inc., Boston, 2006.

[34] D. H. Schunk, Learning Theories: an Educational Perspective. Boston, Allyn \& Bacon, MA, 2012.

[35] A. L. Costa and Kallick, B. "Teaching Habits of Mind". In A.L. Costa and B. Kallick (Eds). Habits of mind across the curriculum: practical and creative strategies for teachers (36-66), Association for Supervision and Curriculum Development, Alexandria, Virginia, 2009.

[36] J. I. Rotgans and H.G. Schmidt, Cognitive Engagement in the Problem Based Learning Classroom, Advance in Health Science Education. vol. 16, pp. 465-479, 2011.

[37] C. D. Wilson, J.A. Taylor, S.M. Kowalski, and J. Carlson, The Relative Effect and Equity of Inquiry-Based and Commonplace Science Teaching on Students' Knowledge, Reasoning, and Argumentation, Journal of Research on Science Teaching vol. 47, pp. 276-301, 2010.

[38] K. Gupta, et al. "Validly and Reliability of the California Critical Thinking Disposition Inventory (CCTDI) in Kermanshah University of Medical Sciences," Edu R Med S., vol. 1, pp. 6-10, 2012.

[39] V. Rimienè, "Relationships between Students' Critical Thinking Dispositions, Skills, and Intelligence," Educational Psychology, vol. 24, pp. 6-13 2013.

[40] P. Eggen and K. Kauchak, Educational Psychology: Windows on Classrooms (8th Edition). Pearson Education, Inc, New Jersey, 2010.

[41] K. Tobin, "Social constructivist perspectives on the reform of science education," Australian Science Teachers Journal, vol. 36, pp. 29-35, 1990.

[42] B. Joyce, M. Weil, and E. Calhoun, Models of Teaching (3th Edition), Pearson Education, Inc., Boston, MA, 2009. 
